\title{
The Question of Creativity in the Finnish Elementary School Curriculum
}

\author{
Juha T Hakala, Taru Konst, Kari Uusikylä \& Esa-Matti Järvinen \\ University of Jyväskylä \\ Kokkola University Consortium \\ P.O Box 567, FI-67701 Kokkola
}

Received: June 7, 2017 Accepted: August 13, 2017 Published: August 13, 2017

doi:10.5296/jse.v7i3.11363 URL: https://doi.org/10.5296/jse.v7i3.11363

\begin{abstract}
This article is intended to examine the role of creative education in the design of the national curriculum and the division of lesson hours during the period 2010-2014. During this process, pupils, private citizens and experts from different fields were given the opportunity to submit their contributions to the exercise. The article intends to examine whether the curriculum development exercise fulfilled the conditions for a wide democratic consultation process. Three professional groups, elementary school teachers, artists (writers, visual arts teachers, musicians) and academic engineers $(n=1163)$ were the main focus of this research project. Creativity related claims, which were posted on the internet, were presented to the research subjects. The results from the study indicated that in many respects, the subjects' concept of creativity and creative education differed statistically from each other considerably. The views from the teachers and artists revealed that creativity is seen as a source of joy and wellbeing. Engineers tend to view creativity from its utilitarian perspective, particularly with reference to product development and innovation. The results also reveal the challenges of developing a national curriculum through a wide democratic consultation process, an apparently simple exercise, which however failed in its objectives and intentions.
\end{abstract}

Keywords: curriculum, elementary school, creativity, educational policy, improving school 


\section{Creativity as a part of national policy}

In line with the Decree on the Development Plan for Education and Research (987/1998), every fourth year the Finnish government is obliged to devise an education and research development programme, which covers all forms of education from preschool to university for a period of five years. In practice, however, every government in power at the time makes its own policy decisions, which have a wide bearing on how educational services are planned, implemented and developed. In this article we intend to examine some of those policy decisions and how they have affected the education policy in general.

For the purposes of this article, the starting point for our examination was summer 2003 when the centre right government of Prime Minister Matti Vanhanen decided to include a creativity strategy for Finland in its cultural policy programme. The impetus for this strategy was influenced by Finland's economic success story during the late 1990s - which was referred to as the Nokia-driven boom (Wilenius 2006, 43-44; see also Castells \& Himanen 2002; Taipale 2013, 3). (Before being sold to Microsoft in 2013, the Finnish telecommunications giant used to be the biggest mobile phone manufacturing company in the world.) Largely as a result of this, Finland began to be touted as a shining model of innovation and creativity. Also widely in circulation at this time were the creative economy theories espoused by the economic geography academic Richard Florida, in particular during the telecommunications boom when he published his two creativity centred works in 2002 and 2005. Other innovative and creativity related works by Paija (2001), Benner (2003), as well as Florida \& Tinagli (2004) confirmed Finland as the home of "national creativity". The government of Prime Minister Vanhanen was determined to maintain and polish this brand image.

Innovation was the global watchword when Finland decided to implement its creativity strategy. The fast economic growth experienced by Asian countries, such as South Korea, India and China was entirely being attributed to innovation and creativity (Oakley 2006, 257-259).Fostering creativity and innovation at higher education institutions was viewed as a necessary ingredient for economic growth (Tiberghien, 2007). Among policy makers and their intellectual backers, the creativity strategy was viewed as the wonder drug that would propel little Finland into an era of unbridled prosperity (Cronberg, 2012). The strategy process was implemented by a team of experts from many fields and was completed in 2006. The last report contained the vision that by 2020, the Finnish society would value creativity induced action and take steps to encourage it. Obstacles to creativity have to be removed. The creativity strategy report also talked about schools, but at this stage, in a roundabout way, with the Finnish Board of Education publishing a book on creative pedagogy. The book, among other things, posed the question: What kind of school studies are capable of generating creativity and innovation? (Finnish Board of Education, 2006). At this point, it is necessary to remark that creative education was, at this time, still regarded as an integral part of the elementary school art studies programme.

From the point of view of our article, the most interesting thing was the next phase of the creative strategy process in which the Finnish educational system became closely connected with the competitiveness discourse. The creative strategy outlined in Prime Minister Matti 
Vanhanen's first term of office continued into the second, now rebranded as the innovative strategy, which was formulated, by a group of experts in 2007. The group completed its work in 2008. The new strategy was implemented by the Science and Technology Policy Council of Finland, and underlined by its conviction that successful innovations are the cornerstone of national achievement. Based on this conviction, the experts contended that Finland's future prosperity depended on high-quality teaching, research and development work, and could only be sustained by "a broad innovation friendly learning environment" $(2009 ; 4,12)$. The rapid change in rhetoric from creativity to product development-related innovation is observable in the fact that in the 47-page innovation strategy, the word innovation appears 254 times compared to Prime Minister Matti Vanhanen's first administration creative strategy final report, where the word appears only a couple of times.

The Finnish government's creative and innovative strategy perfectly coincided with the European Union's 2009 creativity and innovation theme, which was aimed at encouraging European countries to operate creatively and create conditions for fostering creativity. The underlying conviction was that creativity belonged to all people. Humanity needed art and culture for spiritual nourishment and all people have a right to enjoy the fruits of creativity, so went the reasoning. Furthermore, creativity could be applied and utilised in all sectors of society, such as business, social interaction, politics, research and science, technological development, sports, etc. Innovation was seen as the panacea for all current and future problems, such as global warming and the energy crises. Social innovation, it was believed, could be the solution for the provision of care services to the aging population and society in general. One of the main objectives of the European Year of Creativity and Innovation (EYCI) 2009 was to stimulate debate and discussion in the member states about how creativity skills could be promoted in schools (Redecker et al., 2010).

\section{Curriculum development and participatory democracy}

The curriculum in use at this time dated back to 2004 and the Finnish Board of Education wanted a new one in place at the beginning of the 2016 school year. At the same time, it was also decided that the elementary school subject choice regime and division of lesson hours system to be renewed and a special working group was established for the latter task. This working group presented its findings and recommendations in summer 2010, and suggested that some aspects of the current distribution of lesson hours system should be renewed. The group also recommended changes in creative education and suggested that drama should be taught in elementary schools. It also suggested increasing the amount of lesson hours in art and handicraft subjects, as well as giving more individual opportunities for students in choosing subjects they wanted to study.

In the light of the developments mentioned above, a wide-ranging curriculum renewal exercise was launched in spring 2009, and in line with the new spirit of democratic participation in government (see Luhtakallio, 2012), the Finns were given the opportunity to give their opinion on the issue, as well as the division of lesson hours project. Suggestions and opinions could be submitted orally or in writing at specially convened hearings. Finnish democratic traditions demand that students have to be consulted on any educational 
developments that affect them. The Finnish Children's Parliament, an internet-based organisation that serves as a discussion platform for students between 9 and 13, was invited to submit their opinions. Most of the members of this body indicated that they wanted more creativity based subjects in the curriculum. In 2010, the Finnish Board of Education conducted another net-based survey for around 60000 junior high and vocational school students. Most of the students revealed that they did not really learn much from art subjects. The two surveys mentioned above were part of the Youth Barometer project, organised by the Finnish Youth Research Society and launched in 2009, which revealed that Finnish schools were not giving enough support to youth creativity and art hobbies. The youths also indicated that they wished that more handicrafts would be taught in schools.

In suggesting the changes, the working group mentioned the strengths of the Finnish elementary school system, but also pointed out the societal challenges facing the educational system and the need to guarantee equality in the system. Like the children and the youths, experts involved in creativity oriented activities who submitted their views to the distribution of lesson hours working group suggested that art skills should have a strong position in the curriculum. Visual arts, in particular, were viewed as having the capability to develop children's creativity, critical thinking, sense of independence and consciousness as active and confident citizens of the world. The visual arts teachers were prepared to place visual arts as the learning core for emotional education and creativity, and as a psychological development platform for the right to free expression and personal growth. And for that to be realised, the pedagogical status of visual arts had to be strengthened. Music has to have a compulsory status and enough lesson hours in elementary school education, the 33 music sector actors and organisations demanded. Through art, children and youth can understand the nature and function of creativity. A creative environment, the Academic Engineers and Architects in Finland (TEK) declared, will create the foundation for critical thinking and learning the skills necessary for problem solving.

Overall, the views of the education sector professionals fell somewhere between those of artists and academic engineers. There were also some teachers who pointed out that the overall development of the education system was very important. In general, the views of the educational sector representatives tended to emphasise the development of the whole system rather than, for example, art or handicraft education or the teaching of problem solving skills and techniques. On the whole, the involvement of experts, interest groups, ordinary citizens, youths and children, revealed that participatory democracy can both be a fruitful exercise and a challenging undertaking. The challenges were revealed in the statements concerning creativity, where, depending on the background and interests of the giver, were expressed in different forms and dimensions. Although there was consensus on the need to create the desirable conditions for fostering creativity, there was, however, no agreement on what those conditions were.

The problems of participatory democracy came to the fore in December 2010 when the recommendations on the distribution of lesson hours working group failed to get government endorsement. The Ministry of Education and Culture immediately appointed a new working group in 2011, which submitted its recommendations for administrative comment in spring 
2012. Public hearings were conducted as before, although there were, somehow, fewer submissions than before, and after many twists and turns, on 28 June 2012 the Finnish government endorsed the submitted constitutionally mandated elementary school objectives and the distribution of lesson hours regime (Government Decree, 422/2012).

Apart from determining or endorsing the aims and objectives of elementary school education, as well as the amount of lesson hours, the government also endorsed the increase in the amount of lesson hours devoted to art skills education, indicating that the government agreed that art skills education was vital for stimulating creativity.

\section{The purpose and methods of study}

The tens of thousands of submissions contributed by private citizens, expert and interest groups during the curriculum development exercise showed how a demanding process it is to make changes in curricula. Moreover, it becomes more so if all the participants are not aware of what is being developed or discussed, and how to identify it. The operational starting point for this article is that creativity is both a current and special concept in curriculum development (Marsh 2009, p. 41, p. 128; Maisuria, 2005; Starko, 2005). We are still of the opinion that the role of creative education in curriculum development can be widely discussed, provided there is a reasonable degree of consensus on the basic issues (Burnard, 2011, 140-149). Neither do we claim that creativity is the only phenomenon or subject that has this feature. It does not. We have chosen this topic or theme as a theoretical example of educational reform, as well as a topic or theme for research purposes. The choice is not coincidental either, because similar academic enquiries have been investigated in a number of countries pursuing a neo-liberal reform of the educational system (for example, Banaji et al., 2010; Lucas, Claxton \& Spencer, 2013).

In most of the research literature, creativity is often placed within the realm of giftedness (Runco, 2007, 251-257). Although many researchers refrain from providing a specific definition of creativity (see Plucker \& Makel, 2010, 48), creativity is generally acknowledged to be the ability to recognise contextual relationships, as well as the capacity and courage to create and do unusual things and provide new ideas (Treffinger et al., 2002; Kaufman \& Sternberg, 2010). Creativity can happen in all areas of life. Creativity is also understood to be the ability to benefit from intuition and the capacity to think unconventionally or "outside the box" (Koziol \& Budding, 2008, 125-126). The hallmarks of a creative person are considered to be the ability or capacity to maximise opportunities, exercise flexibility, take risks, break boundaries, be unprejudiced and strive for freedom (Craft, 2010). The capacity to experiment, self-expressiveness, verbal proficiency, vivid imagination, aesthetical awareness, as well as the ability to think symbolically, exercise flexibility in decision making processes and adapt to new situations are also considered to be the hallmarks of a creative thinker (Brookhart, 2010, 128-129; Cropley \& Cropley, 2011, 313-320). The ability to find and establish order in chaotic situations is also considered to be one attribute of a creative person (Wheatley, 2009, 10-12; Cohen, 2006).

According to current thinking, creativity refers to divergent thinking: the ability to approach issues from different angles and the ability to see alternative solutions to problems. Creativity 
is not only related to arts subjects or the so-called creative fields (Confederation of Finnish Industries, 2011) but it is imagining alternative solutions to problems while innovativeness is the ability to put these ideas into practice. Education that promotes creativity and innovativeness adopts methods from working life; experimenting with others without being afraid of making mistakes must be encouraged. This is why future education will focus on competences in addition to knowledge and working in groups and networks instead of working alone (Confederation of Finnish Industries, 2011; Penttilä et al., 2013, 2014).

Earlier both learning and creativity were seen as individual processes. Currently the distributed and collaborative nature of creative processes is emphasised (Littleton et al., 2008; Sawyer, 2003). Creativity is seen as activities of a team or a group. This social dimension of creativity has been described with the terms of collaborative creativity, distributed creativity or creative collaboration (Miell \& Littleton, 2004). In brief, creativity or innovativeness require group input; none of the group members alone is able to achieve similar understanding as the group together. Creativity comes out best through discussion when collaborating, where individuals around a common task or challenge get inspiration from each other (e.g. Schrage, 1995; Collin et al., 2011). Creativity can also be originality or being different and surprising. It is noteworthy, however, that creativity also means the so-called everyday creativity, i.e., seeing alternatives and adopting them in everyday situations. Creativity is a part of everyday intercourse (e.g., Sawyer, 2001) and many creative solutions are produced in social interaction as stated earlier. Thus, creativity can be approached as a very practical issue because it is needed in many everyday activities and problem-solving situations. This sets special challenges on the curriculum implementation if creativity is to be strengthened: it requires more problem-based approaches to learning, more social interaction and teamwork, more tutoring than teaching, new learning environments making this possible, etc.

The research material for this study was collected via internet-based questionnaires, which were sent to the three professional groups (teachers, artists and engineers) involved in the creativity discussion related to the curriculum development process in spring 2014. The aim of the research questions was not so much to find out how the above mentioned attributes of creativity are expressed or treated by the three professional groups but, rather, to find out to what extent their views or perspectives on creativity differ from each other. The main question was: What are the dimensions or aspects of creativity and creative education related to the 2010-14 curriculum renewal process, in which the views of the three expert/professional groups differ most? Additionally the reasons for the differences are considered.

\section{Research process}

The subjects of this research project are the three groups of professionals associated with the concept of creativity within the context of the curriculum renewal process: 1) elementary school teachers, 2) artists (writers, visual artists and music sector players) and 3) academic engineers. Because of the nature of their work - close and constant interaction with students teachers are probably the best group of experts to say what creativity and creative education 
is or should be like at school. The work of writers, visual artists and music professionals is all centred on creativity, and their choice as commentators on the subject is warranted. In their work, engineers are involved in technical processes such as research and product development, as well as innovation related activities, and as such, they can also provide a valuable angle to the issues of creativity and creative education. The survey questionnaire was sent to the respondents' trade union by email, and circulated on social media sites, such as Facebook. Respondents had to open the provided link and anonymously fill in the questionnaire. At the end of the questionnaire, the respondents had to state the length of their work experience.

The survey questionnaire contained 37 attitude claims, with 13 of them seeking to determine the concept of creativity in general terms ("Creativity is everywhere, but many do not recognise it.") Eight claims were intended to establish a link between a creative person and creativity related action with statements, such as: "Creativity requires a free and open environment to flourish." The last part of the questionnaire contained 16 statements related to elementary school education and creativity ("The present education system constricts creativity").

One reliability related problem with online or postal questionnaires is that the people who answer may already be predisposed to the issue under investigation and thereby skew the results of the investigation. To eliminate this obstacle, the survey questionnaire was sent to hundreds of respondents from each of the professional groups. Altogether, over a period of one month, 1163 responses were collected from 563 arts representatives, 403 school teachers and 354 engineers. Another problem with online questionnaires is that they can only be filled or completed by a person or persons with access to the internet, email and social media channels. For this study, we operated on the assumption that all the groups of professionals participating in the exercise had access to these communication channels in their work.

Another major problem with online surveys is the preservation of information security, particularly with reference to the confidentiality or privacy of the respondent. To protect the respondents' confidentiality and privacy, the questionnaire was sent directly to their addresses, and after one month, the link to the survey questions was automatically closed. Because the overall aim was to examine all the responses, they were reported upon as a constituent group. This, as well as the confidentiality of the responses, was communicated to the respondents beforehand.

The response results were subjected to tests of significance to determine the validity of claims from the sample. The frequency distribution of the data was assigned an absolute and a relative value. Data scatter was measured in the traditional way by utilising the mathematical concepts of the mean, scatter and skew. The distributional skew of the data were subjected to the chi-square $\left(\chi^{2}\right.$-test). Expert group comparison was conducted via the mean value test [analysis of variance analysis (ANOVA)] method. 


\section{Research results}

The research results confirm the hypothesis that the three expert groups chosen for the analysis have different views and opinions, not only about creativity but also about creative education. In examining the results we concentrated on differences that were statistically meaningful or significant $(\mathrm{p}=.000)$, and although some differences were not statistically significant, they were nevertheless meaningful for our research purposes.

Teachers, more than artists or engineers were more inclined to agree with the statement "Creativity is everywhere, but many are not aware of it." Compared to the two other groups, the mean value difference from the response given by the teachers was significant at $(\mathrm{p}<.01)$. All the research participants unanimously agreed with the following claim: "We are all endowed with creative abilities." And, once again, teachers were more positive than the two other groups in endorsing this statement. Engineers, on the other hand, were more guarded in affirming this assertion about hidden creative abilities $(p=.000)$. On the other hand, artists, more than teachers and engineers, were more firmly convinced that: "Everyone is born creative but loses it with time" ( $\mathrm{p}=.000)$. Teachers and engineers, on the other hand, were more guarded in their responses to this statement. However, despite this variation, there were no significant differences in the views and opinions of teachers and engineers.

Table 1. Paired comparison among three groups

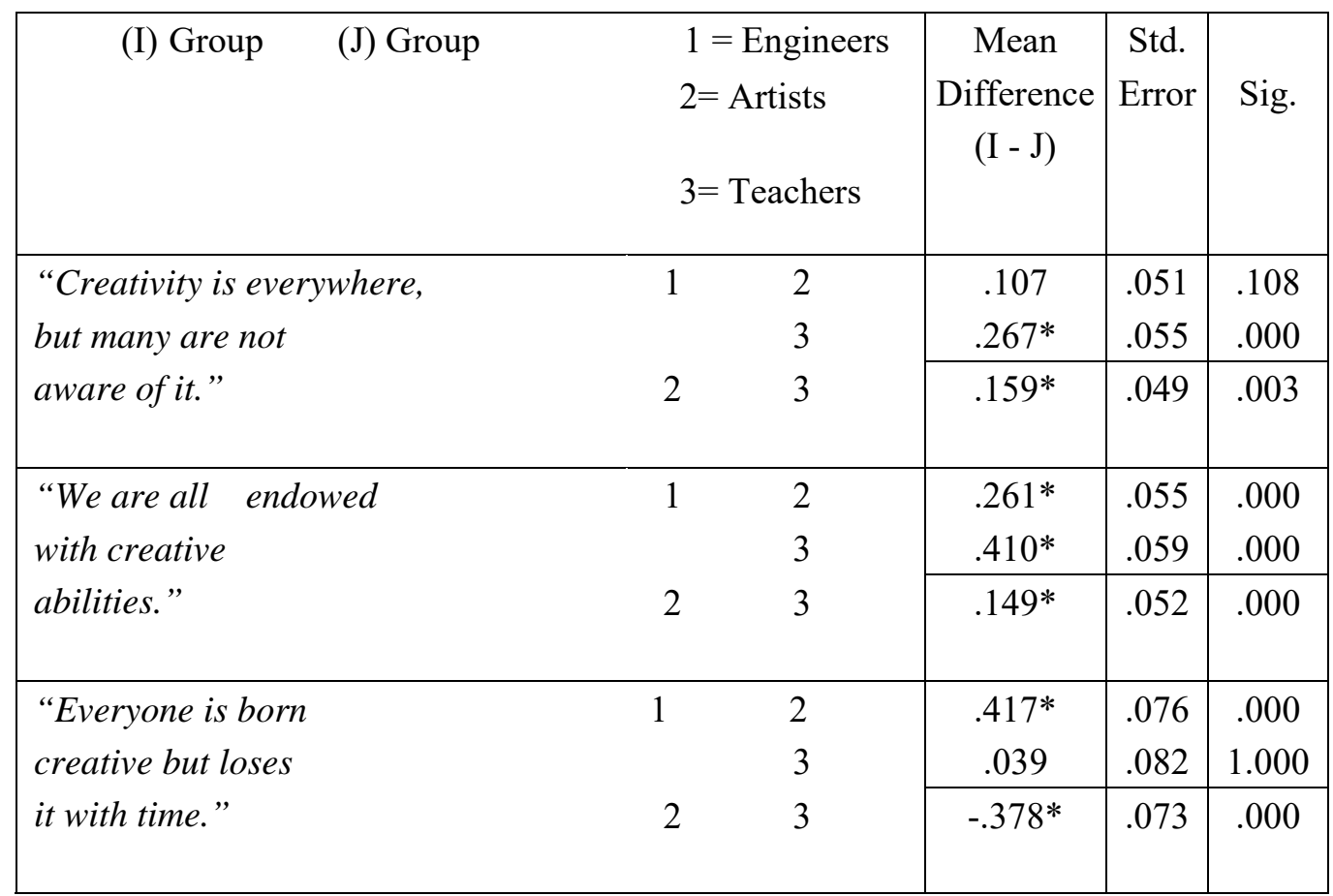

Based on the abovementioned results, teachers, compared to other two groups, are more optimistic about the benefits of creative education than artists or engineers. This optimism could be the result of them being constantly exposed to the creative potential of children and youths, and an ability to recognise gifted individuals. On the other hand, there is a palpable sense of suspicion bordering on cynicism in the responses given by engineers. And from the 
look of it, the belief that technological innovation can spur economic growth has been strongly dented, particularly among the university level educated technological professionals and, to some extent, also among artists.

The same creativity-innovation discussion also touches on the survey statement, "We Finns have not been able to adequately exploit our creative potential." The views and opinions of engineers and artists diverged widely on this statement, with the latter group much more guarded than the former $(\mathrm{p}=.000)$. According to the artists, Finns have not been able to adequately exploit the potential benefits from creativity. The views and opinions of both groups differed widely on the statement:"Creativity is claimed to be a valued attribute, but in practice nothing is being done about it." Artists unanimously agreed with this statement, hardly a surprising assessment given the fact that they have long complained about the hollowness of creativity liturgy. According to them, creativity is spoken of in glowing positive terms in public because this is how it should be, but in practice, nothing is being done to promote creativity and creative pursuits. This criticism is quite understandable because, like in other countries, artists have to struggle to earn a living from their work. In Finland, there is also stiff competition for arts scholarships and the professional peace of mind that they bring. On the whole, it should, perhaps, be borne in mind that artists, by the creative nature of their work, are expected to be critical towards many social trends and assumptions.

Table 2. Paired comparison among three groups

\begin{tabular}{|c|c|c|c|c|c|}
\hline \multirow{2}{*}{$\begin{array}{l}\text { "Us Finns have not been able to } \\
\text { adequately exploit our creative } \\
\text { potential." }\end{array}$} & 1 & $\begin{array}{l}2 \\
3 \\
\end{array}$ & $\begin{array}{c}.255^{*} \\
.149 \\
\end{array}$ & $\begin{array}{l}.059 \\
.063 \\
\end{array}$ & $\begin{array}{l}.000 \\
.055 \\
\end{array}$ \\
\hline & 2 & 3 & .106 & .056 & .180 \\
\hline \multirow{2}{*}{$\begin{array}{l}\text { "Creativity is claimed to be a valued } \\
\text { attribute, but in practice nothing is } \\
\text { being done about it." }\end{array}$} & 1 & $\begin{array}{l}2 \\
3\end{array}$ & $\begin{array}{l}.521^{*} \\
.222^{*}\end{array}$ & $\begin{array}{l}.058 \\
.062\end{array}$ & $\begin{array}{l}.000 \\
.001\end{array}$ \\
\hline & 2 & 3 & $-.299 *$ & .055 & .000 \\
\hline \multirow{2}{*}{$\begin{array}{l}\text { "Current lifestyle trends are } \\
\text { detrimental to promoting } \\
\text { creativity." }\end{array}$} & 1 & $\begin{array}{l}2 \\
3\end{array}$ & $\begin{array}{l}.319 * \\
-.024\end{array}$ & $\begin{array}{l}.080 \\
.085 \\
\end{array}$ & $\begin{array}{c}.000 \\
1.000 \\
\end{array}$ \\
\hline & 2 & 3 & $-.343 *$ & .076 & .000 \\
\hline \multirow{2}{*}{$\begin{array}{l}\text { "The current creativity discussion is } \\
\text { too dominated by the economic } \\
\text { growth perspective." }\end{array}$} & 1 & $\begin{array}{l}2 \\
3\end{array}$ & $\begin{array}{l}.917^{*} \\
.393^{*} \\
\end{array}$ & $\begin{array}{l}.072 \\
.077 \\
\end{array}$ & $\begin{array}{l}.000 \\
.000 \\
\end{array}$ \\
\hline & 2 & 3 & $-.524 *$ & .069 & .000 \\
\hline \multirow[t]{2}{*}{$\begin{array}{l}\text { "In working life there is growing } \\
\text { pressure to be more productive } \\
\text { than creative." }\end{array}$} & 1 & $\begin{array}{l}2 \\
3 \\
3\end{array}$ & $\begin{array}{l}.249^{*} \\
.080 \\
-169 *\end{array}$ & $\begin{array}{r}.057 \\
.061 \\
054\end{array}$ & $\begin{array}{r}.000 \\
.559 \\
006\end{array}$ \\
\hline & 2 & & $-.109^{\circ}$ & .054 & .000 \\
\hline
\end{tabular}

The results of the survey also reveal the frenetic changes taking place in a postmodern society, in which people never seem to have enough time despite the proliferation of labour saving 
devices and appliances. For the creative people, this hectic environment is an anathema to creativity. This, combined with a pessimistic vision of the progression of the economy, has convinced artists, teachers and engineers that "current lifestyle trends are detrimental to promoting creativity". Artists differed considerably from the other two groups in their reaction to this statement $(\mathrm{p}=.000)$. Also, unlike teachers and engineers, artists do not wholly subscribe to the notion that "The concept of creativity is still largely associated with the work of artists." Teachers, unlike artists and engineers, wholly agreed with this statement $(\mathrm{p}<.01)$.

The claim "The current creativity discussion is too dominated by the economic growth perspective" elicited strong divergent responses from both groups $(\mathrm{p}=.000)$. The most critical group was the artists who are often, unlike teachers and engineers, opposed to linking the creativity discussion with economic activities and interests. The artists 'response also reveal this group's cynicism towards the "creativity is valuable" rhetoric. The results also reflect anxieties about current cuts in public spending, by which schools have been affected, with public funds being increasingly channelled to sectors that have economic potential. And, once again, the views and opinions of teachers fall somewhere between those of artists and engineers. All the three groups agreed with the assertion "In working life there is growing pressure to be more productive than creative." Artists were more in accordance with this statement than teachers and engineers, and the difference between the views and opinions of artists and engineers was statistically significant $(\mathrm{p}=.000)$.

However, despite the differences in the views and opinions of all three groups, all teachers, artists and engineers were concerned about the establishment of a favourable environment for creativity, and unanimously concurred with the statement: "Creativity needs an open and free environment to flourish." Furthermore, artists, more than teachers and engineers, thought that creativity required more than just an open and free environment. They were also of the opinion that creativity required a certain degree of uncertainty. This difference was reflected in the statement: "Risk avoidance (for instance in business) stifles creativity." Artists concurred much more with this claim than teachers $(p=.000)$. And unlike teachers and engineers, they were much more inclined to the belief that "a creative person should mess things up." The difference between artists and engineers on this score was statistically significant $(\mathrm{p}<.01)$. 
Table 3. Paired comparison among three groups

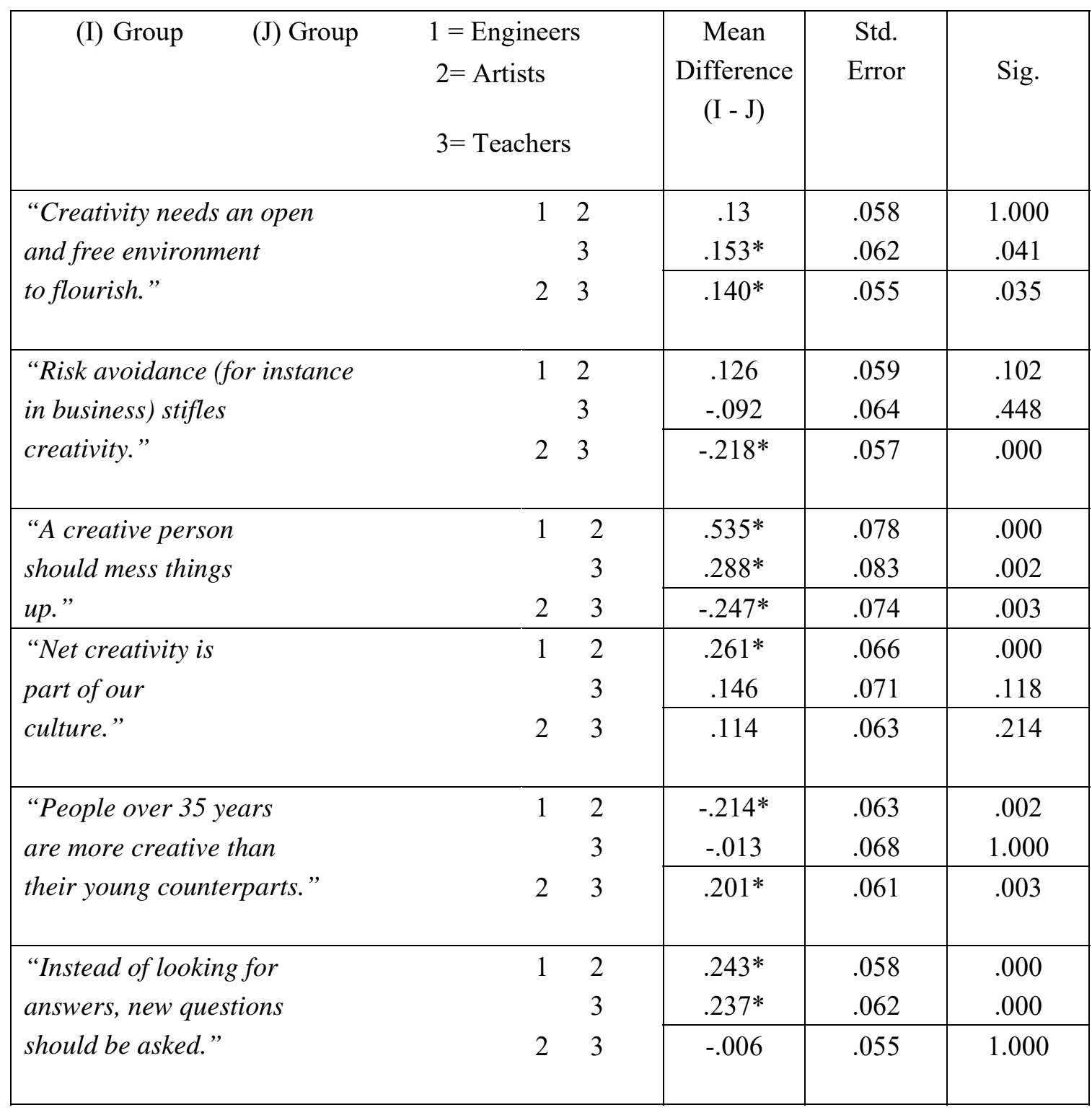

The research study was also aimed at defining creativity with the context of cultural change by, for instance, asserting that: “Net creativity is part of our culture." The results reveal that the information technology based society is regarded as part of modern culture. All the respondents agreed with the claim but, surprisingly, artists, more than engineers, regarded net creativity as a component of modern culture $(\mathrm{p}=.000)$. The creative potential of young people coming into the labour market is appreciated by the respondents with, of course, some notable differences on how the issue is perceived. In this regard, artists, more than teachers and engineers, disputed the claim "People over 35 are more creative than their young counterparts." ( $\mathrm{p}<.01)$. All the respondents concurred with the claim "Instead of looking for answers, new questions should be asked." But, again, there were some differences in how this issue was perceived. Teachers and artists were more in agreement with this statement than the engineers $(p=.000)$. 


\section{Summary and conclusion}

The results from the survey reflect the different views about creativity in the three professional groups. Among all the three professional groups, engineers are the most sceptical about this possibility, which implies that "there is a gem of creativity in us all." The members of all three professional groups are of the same opinion that preschool children are quite creative in their behaviour. They however, differ in their views on the nature and practice of creativity in schools. According to the results of this survey, art practitioners (writers, visual artists and professional musicians) are the most sceptical about the capability of schools to foster creativity in students and youths, and strongly subscribe to the view that "Schools kill creativity." Apart from the art practitioners, engineers also hold distinct views about creativity, and unlike the former, do not believe that it is a complex, agonising process, which requires courage and determination to break away from the comfort zone. Like artists, engineers are also inclined to the view that creativity is a process that requires time to develop and bloom.

All this makes one wonder what type of curriculum, particularly with reference to creativity, will Finnish elementary schools get in 2016. Will it be a hotchpotch of programmed views and expectations on creativity, and where will the required time for its incubation and maturity come from? What will be the proportion of skills and knowledge in the new curriculum? And what about the role of the much talked about general education in basic and upper education levels (Smith \& Smith, 2010, 251)? Moreover, to what extent can creativity be promoted by integrating school subjects? How does this measure up in an educational culture where children and youths are expected to pass tests? (Ball, 2008; Kalalahti \& Varjo, 2012)

Artists, it appears, are frustrated by the fact that Finland has not been able to make its mark on the global creativity stage. This frustration is also, to some extent, a criticism of the Finnish education system. On the international stage, Finnish creativity has been notable within the information technology sector - mobile phones and their applications, as well as computer games etc., and one wonders whether there is any link between this and creative education. Artists' pessimistic assessment of creativity can also be viewed as a reflection of their frustration with the current support system for creative arts. Although there are some permanent support systems for artists, they are more vulnerable to cuts than other sectors during times of economic recession, and this has a negative impact on both employment and the supply of creative education opportunities.

The views of teachers and artists in the survey reveal a fundamental belief that creativity can increase social welfare and happiness. Creativity is, of course, very much associated with economic prosperity, but this does not need to always be the case (see. Banaji et al., 2010, 23). However, it is interesting to note that this phenomenon is distinctly present in the Finnish government's creative strategy. In 2006, the centrepiece of Prime Minister Matti Vanhanen's creative strategy was on enhancing human welfare. During his second administration in 2009 the emphasis had shifted to promoting economic growth and prosperity, a strategy that was also given moral support by the Finnish Confederation of Industries in 2011 when it released 
the results of a study intended to examine the economic skills and capabilities required for the future. The study also revealed one unexpected fact about social media use - most of the artists did not have valid email addresses through which the survey questionnaires could be sent. This was quite surprising for a professional group that has, among other things, contemplated the various dimensions of the relationship between creativity and social media.

Of all three professional groups, the responses from the engineers were most closely aligned to economic developments, and in their view creativity was a useful national pursuit, as long as it promoted product development and innovation (see Hautamäki \& Ståhle, 2012, 9; Massaro, Bardy \& Pitts, 2012). The views of the engineers on this issue clearly coincided with those of the government's 2008 official report on innovation policy, which defined creativity as a phenomenon "benefiting from advantages accruing from competitive advantages". This view should be examined in the light of the national and global economic downturn, which was still continuing as summer 2014 approached. It is quite valid to assume that the responses given by the engineers were, to some extent, widely influenced by the sale of Nokia to Microsoft a year before. This, together with the fact that unemployment among engineers was rising as summer approached, seems to have increased pessimism about the role of high tech in propelling Finland towards economic prosperity. In the background, there are also the effects of the educational reforms that were carried out at vocational and higher education levels ostensibly to increase employment within the creative sectors. Apart from the reduction of education opportunities in these sectors, the reforms have also distressed arts practitioners who fear that this will lead to the reduction of creative content in the national curriculum.

In all, the research results indicate that national discussion about creative education can be both interesting and useful, particularly when there are tens of thousands of participants (including hundreds of experts in the field). The results are different perspectives and opinions on creative education - from experts, as well as ordinary people. The question that crops up from this lively discussion is: To what extent can all the different perspectives and opinions about creativity be incorporated into a long term national curriculum?

There are also some reasons to be critical about the nationwide participation to formulate a democratic national curriculum. Participants have the right or at least reassurance that their views and opinions have to be incorporated in the final outcome. Failure to do that is a betrayal of trust. It is quasi democracy, which the critics of neo-liberalism have discovered in the educational policies of many European states (e.g. Berezin, 2009; Rinne, 2002, 2004; Hilpelä, 2004; Varjo, 2007).

Yet another problem with nation-wide participation in designing a national curriculum is the fact that global economic demands have an effect on how schools are run, and this, of course, includes the curriculum. According to the neo-liberal ideology, the school is viewed as a kind of future engine to generate economic growth and prosperity. The content of the curriculum may be based on sound educational principles but, in the end, economic realities will determine its shape and scope (see Habermas, 2006). Because of this, it may be a good idea to entrust the task of designing a national curriculum to experts. After all, national economic 
planning is not implemented by public participation. So, why should curriculum planning be a nationwide exercise? The answer "because it affects all of us" is not good enough because the economy has an effect on all facets of our lives as well. The purpose of education is a humanistic task, which is not only an advantage for an individual and a society but also for an economy, because an economy does not flourish in a society where people act only as producers and consumers. In addition to providing people with new competences required at work, education must support them to develop as constructive, critical and creative citizens. Education has an important role in ensuring creative capacity of students, who need to be able to meet a satisfying future. A curriculum with educational solutions, which encourages the development of creativity, emphasizes problem solving and interaction competences and supports students' personal interests, best endorses their ability both renew and transfer their learning to new situations.

\section{References}

Ball, S. J. (2008). The Education Debate. Bristol: The Policy Press.

Banaji, S., Burn, A., \& Buckingham, D. (2010). The Rhetorics of Creativity: A literature review. 2nd edition. London: Creativity, Culture and Education.

Benner, C. (2003). Learning communities in a learning region: the soft infrastructure of cross-firm learning networks in Silicon Valley. Environment and Planning A, 35, 1809-1830. https://doi.org/10.1068/a35238

Berezin, M. (2009). Illiberal Politics in Neoliberal Times. Culture, Security and Populism in the New Europe.

Brookhart, S. M. (2013). Assessing Creativity. Educational Leadership, 70, 28-34.

Burnard, P. (2011). Creativity, Pedagogic Partnerships, and the Improvisatory Space of Teaching. In: Sawyer, R. K. (Eds.). Structure and Improvisation in Creative Teaching. New York: Cambridge University Press. 51-72. https://doi.org/10.1017/CBO9780511997105.004

Castells, M., \& Himanen. P. (2002). The Information Society and the Welfare State. The Finnish Model. Oxford: Oxford University Press. https://doi.org/10.1093/acprof:oso/9780199256990.001.0001

Cohen, G.D. (2006). Research on creativity and ageing: the positive impact of arts on health and illness. Journal of the American Society on Aging, 30, 7-15.

Collin, K., \& Billett, S. (2011). Luovuus ja oppiminen työssä. In K. Collin, S. Paloniemi, H. Rasku-Puttonen \& P. Tynjälä (Eds.), Luovuus, oppiminen ja asiantuntijuus. Helsinki: WSOY.

Craft, A. (2010). Creativity and Education Futures: Learning in a Digital Age. Staffordshire: Trentham Books Ltd.

Cronberg, T. (2012). Estejuoksu luovaan Suomeen. Sastamala: Kunnallisalan kehittämissäätiön julkaisuja 86. 
Cropley, A., \& Cropley, D. (2011). Creativity and Lawbreaking. Creativity Research Journal, 23, 313-320. https://doi.org/10.1080/10400419.2011.621817

Confederation of Finnish Industries. (2011). Oivallus final report. Retrieved from http://ek.fi/wp-content/uploads/Oivallus_loppuraportti.pdf

European Union (2009). European Year of Creativity and Innovation 2009. Retrieved from http://www.create2009.europa.eu/about_the_year.html

Finland's National Innovation Strategy. (2008). Publications of Ministry of Employment and the Economy in Finland. Helsinki: Ministry of Employment and the Economy.

Florida, R. (2002). The Rise of the Creative Class: And How It's Transforming Work, Leisure, Community and Everyday Life. New York: Basic books.

Florida, R. (2005). The Flight of the Creative Class: The New Global Competition for Talent. New York: HarperCollins.

Florida, R., \& Tinagli, I. (2004). Europe in the Creative Age. London: Demos.

Government Decree 987/1998. (1998). Asetus koulutuksen ja yliopistoissa harjoitettavan tutkimuksen kehittämissuunnitelmasta.

Government Decree 422/2012. (2012). Valtioneuvoston asetus perusopetuslaissa tarkoitetun opetuksen valtakunnallisista tavoitteista ja perusopetuksen tuntijaosta.

Habermas, J. (2006). Political Communication in Media Society: Does Democracy Still Enjoy an Epistemic Dimension? The Impact of Normative Theory on Empirical Research. Communication Theory 16, 411-426. https://doi.org/10.1111/j.1468-2885.2006.00280.x

Hautamäki, A., \& Ståhle, P. (2012). Ristiriitainen tiedepolitiikkamme: Suuntana innovaatiot vai sivistys? Helsinki: Gaudeamus.

Hilpelä, J. (2004). Järjen epäilyä ja suunnittelemattomuuden ylistystä - ekskursio uusliberalistiseen koulutuspolitiikkaan. Kasvatus, 35, 55-65.

Kalalahti, M., \& Varjo, J. (2012). Tasa-arvo ja oikeudenmukaisuus perusopetukseen sijoittumisessa ja valikoitumisessa. Kasvatus ja aika 6.

Kaufman, J. C., \& Sternberg, R. J. (Eds.). (2002). Cambridge handbook of creativity. New York: Cambridge University Press.

Koziol, L. F., \& Budding, D. E. (2008). Subcortical Structures and Cognition Implications for Neuropsychological Assessment. New York: Springer Verlag.

Littleton K., Rojas-Drummond S., \& Miell D. (2008). Introduction the special issue: Collaborative Creativity: Socio-Cultural Perspectives. Thinking Skills and Creativity 3(3), 175-176. https://doi.org/10.1016/j.tsc.2008.09.004 
Lucas, B., Claxton, G., \& Spencer, E. (2013). Progression in Student Creativity in School: First Steps Towards New Forms of Formative Assessments. OECD Education Working Papers, No. 86: OECD Publishing. https://doi.org/10.1787/5k4dp59msdwk-en

Luhtakallio, E. (2012). Practicing Democracy. Local Activism and Politics in France and Finland. Hampshire: Palgrave Macmillan. https://doi.org/10.1057/9780230363519

Maisuria, A. (2005). The turbulent times of creativity in the national curriculum. Policy Futures in Education, 3, 141-152 https://doi.org/10.2304/pfie.2005.3.2.3

Marsh, C. J. (2009). Key Concept for Understanding Curriculum. New York: Routledge.

Massaro, M., Bardy, R., \& Pitts, M. (2012). Supporting creativity through knowledge integration during the creative processes. A management control system perspective. The Electronic Journal of Knowledge Management, 10, 258-267.

Miell, D., \& Littleton, K. (2004). Collaborative creativity: Contemporary perspectives. London: Free Association Books.

Ministry of Education and Culture (2004). Luovuuskertomus. Ehdotus hallitusohjelmassa tarkoitetun luovuusstrategian tekemisen luonteesta, lähtökohdista ja toteuttamisen tavoista. Helsinki: Opetusministeriön julkaisuja 4.

Ministry of Education and Culture (2005). Kolme puheenvuoroa luovuuden edistämisestä. Luovuusstrategian osatyöryhmien raportit. Helsinki: Opetusministeriö. Kulttuuri-, liikunta- ja nuorisopolitiikan osasto.

Ministry of Education and Culture (2006). Yksitoista askelta luovaan Suomeen. Luovuusstrategian loppuraportti. Helsinki: Opetusministeriön julkaisuja 43.

Ministry of Education and Culture (2009). Luova talous ja kulttuuri innovaatiopolitiikan ytimessä. Helsinki: Opetusministeriönjulkaisuja 30.

Oakley, K. (2006). Include Us Out-Economic Development and Social Policy in the $\begin{array}{lllll}\text { Creative } & \text { Industries. } & \text { Cultural } & \text { Trends, } & 15,\end{array}$ https://doi.org/10.1080/09548960600922335

Oivallus-loppuraportti (2011). Final report. Helsinki: Elinkeinoelämän keskusliitto.

Paija, L. (2001). The ICT Cluster in Finland - The Engine of Knowledge-driven Growth in Finland. Innovative Clusters. Drivers of National Innovative Systems. OECD. Organisation for Economic Co-operation and Development. 19-43.

Penttilä T., Kairisto-Mertanen L., Putkonen A., \& Lehto A. (2014). Innovaatiokompetensseja innovaatiopedagogiikan avulla. In P. Rautkorpi- Mutanen \& L. Vanhanen-Nuutinen (Eds.), Kestävä innovointi. Oppimista korkeakoulun ja työelämän dialogissa. Metropolia ammattikorkeakoulun julkaisusarja, 156-171. Helsinki: Unigrafia.

Penttilä T., Kairisto-Mertanen L., Putkonen A., \& Lehto A. (2013). Innovation pedagogy - A Strategic Learning Approach for the Future. In A. Lehto A. \& T. Penttilä (Eds.), Pedagogical 
views on innovation competences and entrepreneurship. Tampere: Reports from Turku University of Applied Sciences 171, 11-23.

Plucker, J. A., \& Makel, M. C. (2010). Assessment of creativity. In J. C. Kaufman \& R. J. Sternberg (Eds.), Cambridge handbook of creativity. New York, NY: Cambridge University Press. 48-73. https://doi.org/10.1017/CBO9780511763205.005

Redecker, C., Ala-Mutka, K., \& Punie, Y. (2010). Learning 2.0 - The Impact of Social Media on Learning in Europe. European Commission. Joint Research Centre. Institute for Prospective Technological Studies.

Rinne, R. (2002). Kansallisen koulutuspolitiikan loppu? In R. Honkonen (Ed.), Koulutuksen lumo - retoriikka, politiikka ja arviointi. Tampere: Tampereen yliopistopaino, 93-119.

Rinne, R. (2004). Suomalainen korkeakoulupolitiikka ylikansallisessa talutusnuorassa. In J. Löfström, J. Rantala \& J. Salminen (Eds.), Esseitä historiallis-yhteiskunnallisesta kasvatuksesta. Helsinki: Historiallis-yhteiskuntatiedollisen kasvatuksen tutkimus- ja kehittämiskeskuksen tutkimuksia 2, 139-166.

Runco, M. (2007). Creativity: Theories and Themes, Research, Development and Practice. Burlington MA: Academic Press.

Sawyer K. R. (2003). Group Creativity. Music, theatre, collaboration. New Jersey, Mahwah: LEA.

Sawyer K. (2001). Creating conversations. Improvisation in everyday discourse. New Jersey: Hampton Press.

Schrage M. (1995). No more teams! Mastering the dynamics of creative collaboration. New York: Currency Doubleday.

Sternberg, R. J., \& Kaufman, J. C. (2010). Constraints on creativity: Obvious and not so obvious. In J. C. Kaufman \& R. J. Sternberg (Eds.), Cambridge handbook of creativity. New York: Cambridge University 467-482. https://doi.org/10.1017/CBO9780511763205.029

Starko, A. J. (2005). Creativity in the classroom: Schools of curious delight. New Jersey, USA: Lawrence Erlbaum Publishers.

Taipale, S. (2013). Mobilities in Finland's Information Society Strategies from 1995 to2010. Mobilities, 8, 293-311. https://doi.org/10.1080/17450101.2012.655975

Tiberghien, Y. (2007). Entrepreneurial states: Reforming corporate governance in France, Japan, and Korea. New York: Cornell University Press.

Treffinger, D. J., Young, G. C., Nassab, W.C., \& Wittig, C.V. (2004). Talent Development: The Levels of Service Approach. Waco, TX: Prufrock Press. 
Varjo, J. (2007). Kilpailukykyvaltion koululainsäädännön rakentuminen: Suomen eduskunta ja 1990-luvun koulutuspoliittinen käänne. Helsingin yliopisto. Kasvatustieteen laitoksen tutkimuksia.

Wheatley, M. (2009). Leadership and the New Science: Discovering Order in a Chaotic World. San Francisco: Berrett-Koehler Publishers.

Wilenius, M. (2006). Yhteiskunta, tulevaisuus ja ennakointi. In R. Heiskala \& E. Luhtakallio (Eds.), Kuinka Suomesta tuli kilpailukyky-yhteiskunta. Helsinki: Gaudeamus. 